\title{
LAND SPECULATION AND URBAN RENT IN TURKEY
}

\author{
TÜRKIYY'DE ARSA SPEKÜLASYONU VE KENTSEL RANT
}

\author{
Semih Halil EMÜR ${ }^{1}$ ID. Seçil Gül MEYDAN YILDIZ ${ }^{2}$ ID
}

\begin{abstract}
The content and impact of rent is increasingly seen as related with the historical period that shaped urban structure depending on the rent relations, changing of life requirements and the scientific and technological developments. The land speculation which is a result of private property is an important factor in the selection of land use decisions and defining the direction of urban development growth. As a natural result of urbanization and being urbanized, the specification of urban land and gainings to the owners are changing due to the increase of social, economic, political and spatial requirements. Attitudes and behaviors contrary to reconstruction (planning) decisions increase the land speculation. In this case, land can become a tool for the storage of wealth depending on the relative position of land in the urban area or being on the direction of urban development. In this study, it is aimed to determine the relationship between the urban, land and the rent in Turkey, and the role of land speculation that is influenced in this process is described.
\end{abstract}

Keywords: Rent, Urban Land, Specifications of Urban Land, Turkey.

$\ddot{O} \mathbf{z}$

Tarihi süreçte kentsel yapılanmaların ranta dayalı ilişkilere bağlı olarak şekillendiği ve değişen yaşamsal gereksinimlerin ve bilimsel, teknolojik gelişmelerin ışığında rantın içeriğinin ve etkilerinin arttığı görülmektedir. Özel mülkiyetin bir sonucu olan arsa spekülasyonu, kentsel alan kullanım kararlarının yer seçiminde ve kentin gelişme yönünün değişmesinde önemli bir etkendir. Kentleşmenin ve kentlileşmenin doğal bir sonucu olarak, sosyal, ekonomik, politik ve mekânsal gereksinmelerin artışıla kentsel toprağın nitelikleri ve sahibine kazandırdığı getirileri değişmektedir. İmar kararlarına aykırı tutum ve davranışlar arsa spekülasyonunu artırmaktadır. Bu durumda, toprak, kent içindeki göreli konumuna veya kentsel gelişme yönünde bulunuyor olmasına bağlı olarak servet biriktirme aracı haline gelebilmektedir. Bu çalışmada, kent, toprak ve rant arasındaki ilişkinin belirlenmesi amaçlanmakta olup, bu süreçte etkili olan arsa spekülasyonun rolü Türkiye örneğinde açıklanmaktadır.

Anahtar Kelimeler: Rant, Kentsel Toprak, Kentsel Toprağın Özellikleri, Türkiye.

\footnotetext{
${ }^{1}$ Dr. Öğr. Üyesi, Erciyes Üniversitesi, Mimarlık Fakültesi, Şehir ve Bölge Planlama Bölümü, semihemur@gmail.com

${ }^{2}$ Dr. Öğr. Üyesi, Yozgat Bozok Üniversitesi, Mühendislik Mimarlık Fakültesi, Şehir ve Bölge Planlama Bölümü, secilmeydan@gmail.com
} 


\section{INTRODUCTION: The Conceptual Development of Rent}

Urban rent is a concept which is identified as the epicenter of all contradictions on the accumulation and reproduction of capital (Turan, 2009) and as the main source of urban problems. The word "rent" originates from French word "rente" and its meaning, attribution and source has been evolved deeply (Genel Ekonomi Ansiklopedisi, 1998, p. 763). According to the wide historical reference, rent means the sole source of any kind of wealth in the precapitalist era and property income arising from the statue of the land being under private possession (AnaBritannica, p. 155). In the mediaeval age, there exist feudal-rent, labor-rent, product-rent and money-rent conceptualizations. Labor-rent refers to the practice of non-paid work of peasants for the benefit of landlord for a period of time in the early feudal period. Product-rent is the practice as the conferral of part of the product to the landlord by the peasant (the land administration practice in Turkish-Islamic societies, iqta and timar systems belongs to product-rent). Feudal money-rent is the share which the dependent peasant is obliged to give to the landlord and money-rent is the rent paid by the free peasant to the landlords according to a bilateral contract rent and certain rules which comparatively has capitalist features. According to the contemporary economic understanding rent is defined as the difference between the earning of a production factor and its real supply price or cost of the factor (AnaBritannica, p. 155).

"Land rent" ranks first when rent is analyzed in the economics literature, while rent is the usage price of the land. According to a wider definition, rent is the name of the share which land and other resources (minerals, oil reserves, forests etc.) receive from the production among other factors of production. The reason for the existence of rent is the scarcity of land and its limited nature (Aktan, 1993, pp. 119-120). Accordingly the conceptual basis of the rent is structured on the scarcity, "The nature of the land which cannot be reproduced and transferred provides to the owners of the land a monopolistic privilege" (Keleş, 2014, p. 143). In the definition by Dinler (2008, p. 280), rent is defined as the share from production received by land as a factor of production or as the price of land, rent is the price paid for the utilization of land factors for a period of time.

Rent which is the price paid for the utilization of land factor in original situation in this manner refers to the share from the production paid to the land owners without any real effort. In order to determine rent, if any factors of production (labor, capital, entrepreneurship) are used in the production process, the share of these other factors should be subtracted from the total production (Ertürk, 1995). For this reason, there exists an undeserved income in the rent. In order to deserve any income from the production process, one should employ labor and capital assets. As rent is an undeserved income, labor and capital factors are not involved within this process. Capitalist mode of production, the existence and dynamics of capital accumulation, and developing the relations of production in this context are necessary for existing urban rent (Bahçeci, 2016, p. 125).

One of the conceptual components of rent is the difference. Difference can arise in various areas and lead to excess income. In this way, various rent concepts can be developed on the difference basis. Income arising from ability differences can be named as ability rent, revenue received due to the quality differences can be defined as quality rent. Consumer rent is defined as the difference between the price which the consumer is ready to pay and market price and producer price is the difference between the price which the producer is ready to sell and market price (Dinler, 2008, pp. 282-283). 


\section{METHODS: Rent Theories}

One of the first extensive and consistent explanations of the nature of rent belongs to David Ricardo at the beginning of $19^{\text {th }}$ century. The reason of increasing importance of the rent in this period was the acceleration in food prices due to the pressure from Napoleon wars and increasing population. Classical rent theories do not mention on the problems of land utilization or spatial organizations. The rent theory of Von Thünen on the basis of the equally productive lands circulating and isolated city is the main theory on which spatial organizations and land utilization is structured. In this theory, the privileged position of the center is mentioned and a model which is centrally administrated is defined.

\subsection{The Land Theory of David Ricardo: Differential Rent}

Differential rent which is named as Ricardian Rent as well stems from the land's productivity differentiation and distance from the center. The starting point of rent analysis is the studies of David Ricardo (Genel Ekonomi Ansiklopedisi, 1998, p. 763). Before the studies of Ricardo, word of "Rent" was used as the periodic payments for the rental usage for a period of time. Ricardo argues that rent arises from the meanness of the nature and if the productivity would be equal all over the world, those who have more productive land compared to those who have less productive land would not earn any added value above their own efforts (without labor and capital) (Dinler, 2008). There are three basic assumptions under the rent theory of Ricardo:

Assumption 1 Diminishing Productivity Law: Ricardo argues that the productivity of labor diminishes after a certain point as the level of labor increases on a certain land.

Assumption 2 Increase in Population and Demand and Opening of Less Productive Land for Production: The productivity of lands is not equal on every land. The most productive lands are opened for production but in time as the population and demand increase less productive lands are opened as well.

Assumption 3 Existence of Single Price in the Market: Under perfect competition conditions, each agricultural product has single price. This price is assumed to be equal to the cost of the farmer producing on the least productive land (Dinler, 2008).

In this theory, rents from both intensive and extensive utilization exist. Different levels of production are earned from different lands with different levels of productivity even the same level of labor and capital (variable factors). In other words, the cost of a certain level of production differs according to the productivity level of the land. If the demand for the product increases in line with increasing population and its needs, the price of the product increases as well. The production is carried out starting from more productive land to less productive and rent in the less productive land is lower. Under perfect competition conditions, each agricultural product has a single price and this price is equal to the cost of the agricultural producer with the least productive land (marginal land). Production in more productive lands is carried out with less labor and investment but sold with the same price of the product from least productive land. The owners of the more productive lands earn rent which is equal to the difference between costs of production on different lands. The value added which is earned without spending any effort is called as Ricardian Rent or differential rent (Genel Ekonomi Ansiklopedisi, 1998, pp. 763-764; Dinler, 2008, p. 280). According to Ricardo value added is linked to labor and labor creates value added. And, the revenue arising only from the productivity of land is rent (Ertürk, 1995). Ricardo also defines this rent as the Rent due to the Different Productivity of Land.

In addition to the productivity, closeness to the center creates an undeserved gain for 
the land owners. The transportation costs are less for the lands closed to the center while the transportation costs are higher for the lands distant from the center. This creates a cost difference. There exists an advantage due to the location of the land (Bahçeci, 2016, p. 134). The production costs are determined on the fact that the agricultural producer who produces closer to the center will pay less transportation costs compared to the producer who produces far from center for the same type of agricultural product. Ricardo defines this type of undeserved earning as the Rent Arising from the Different Distances of Land from the Consumption Center.

\subsection{The Land Rent Theory of Karl Marx; Absolute Rent, Differential Rent and} Monopoly Rent

Karl Marx takes the differential rent theory of Ricardo further and developed absolute and monopoly rent concepts. According to Marx (1978, p. 661) "Land ownership itself created rent". Structured on the basis of private ownership the rent consists of the ownership monopoly on the land, the cultivation monopoly of land and the needs and purchasing power of the consumers (Ertürk, 1995, p. 155). Absolute rent is the rent stemming from the ownership monopoly and arising due to the existence of private ownership (Marx, 1978). Kemal Kartal (1977, p. 23) explains the absolute rent approach of Marx in these words: "In case of an increasing demand for a product, the price of that product and the profit received from that product increases as well. In order to produce that product providing high profit rates, new firms are founded. Consequently the supply of the product expands in the market and price of the product and profit rates decrease. However in case of land the quantity of land cannot be increased even if the demand for land increases but the price of land, the income from land which is rent elevates". The scarcity of the land provides rent to the land owner either in the short or long term and this process prevails today as well. The absolute rent arising from the scarcity of land is also called as scarcity rent. It is possible that even the lands with least productivity may provide added value to the owners in the long run (Aktan, 1993, p. 120). Accordingly, the land rent arises from the fact that land is scarce and the supply of land factor cannot be increased. In line with the increasing population, the land currently in use becomes insufficient and the land owners without employing any effort and depending only on their ownership and the scarce characteristic of land receive an excess added value. This added value is defined as absolute rent by Marx. In order to abolish the absolute rent land should be nationalized. By this way only the rent types arising from the productivity differences will exist (Tekeli, 2009, p. 20).

The rent arising from the cultivation of the land is the differential rent (Ertürk, 1995, p. 156). According to Marx (1978, p. 669) the development and enhancement of differential rent conserve its statue both for the constant and increasing prices forward from inferior lands to superior lands and backward from superior lands to inferior lands.

Differential rent arises from the natural difference of productivity of the land. This rent stems from the scarce existence of the superior land area and requires equal capital investment on lands with different productivity levels. Equal level of capital investment leads product levels which are not equal and the price of the product produced on the land with the lowest level of productivity (with no rent) always becomes the market regulating price. The productivity difference of the land can be due to natural reasons and can be improved by the conditioning efforts on the land and investments. The rent due to the needs and purchasing power of the consumers is named as monopoly rent (Ertürk, 1995). Monopoly rent is involved in the competition theory (Marx, 1978). 


\subsection{The Rent Theory of Von Thünen, Spatial (Location) Rent:}

The Rent concept presented by the English economist David Ricardo in 1817 was enhanced and systematically defined as spatial rent in 1826 by the German Von Thünen. While the differential rent of Ricardo was based on the productivity difference of the land, Von Thünen assumes the productivity of land is homogenous. This is the single difference between differential rent and spatial rent (Dinler, 2008, p. 281). Classical rent theories generally study the source of the rent. Within this context these theories do not have the ability to explain spatial organization and urban settlement. The first study on the rent theory with spatial organization is Von Thünen's theory and he as accepted as the founder of spatial economics. Von Thünen in his theory studies the emergence of rent on the lands with equal productivity circling an isolated city. According to Von Thünen, rent arises due to the differentiation of transportation cost related with the distance of the agricultural land from the market city proportionally to the distance and the land owners closer to the market city receive 'spatial rent'. The spatial rent of Von Thünen explains the 'accessibility rent' as well. The transportation cost differences constitute the rent for the land owner. The rent value of the margin of the city is zero. If we try to explain by ignoring other variables and simplifying the costs, the rent at the center will be equal to the transportation cost paid by the owners of the land at the margin of the city. There exists a reverse relationship between rent and transportation costs. Total rent and total transportation costs living in the city are equal. The accessibility rent for the land owner arises in line with the expansion of the city and transportation system and without any effort of the land owner. The reason for this rent is distance namely the geographical position. This rent will not increase against any effort of the land owner without the expansion dynamics of the city (Kilınçaslan, 2010). Furthermore, in Von Thünen's theory, the differentiation in the agricultural lands is also defined. Accordingly in the theory the emergence of agricultural production areas varying on the agricultural product produced on the land (Ertürk, 1995). Single Market, isolated city hinterland and homogenous data and productivity, transportation costs and targeting maximization of the profit constitute the five assumptions of the theory. The reason for the differentiation in the agricultural production regions is the transportation expenditures depending on the distance from the market city. On a homogenous area, as the transportation costs to all direction vary with the same proportion, the production areas will arise in circular forms. The sequencing of these circular areas will be determined on such factors that the spoilage duration of the product and difficulty of transportation. Under these conditions it is argued that the agricultural production areas appear in circular forms around the city (Ertürk, 1995, pp. 173174). Von Thünen's scheme which shows different agricultural areas encircling each other around a city center forms the main structure of the settlement researches of our day. The differential rent theory defined by Ricardo according to the productivity differential is matured by spatial (location) rent, but it should be underlined that Von Thünen assumes the homogeneity of the land productivity. In classical rent theories the arguments do not take the difference of urban or agricultural land into account.

As the urban population in cities increases their needs for the urban land increase in line with the needs of the city life. These needs are primarily are settlement, health, education, leisure, entertainment and requirements of cultural structure. Another requirement of city life is naturally working areas, in other words areas for economic activities. In order to enhance and develop urban life in planned way, there is the need for urban land as some of the functions of urban life urge settlement on the land. This requirement and demand leads to an increase in the value of land on the growth direction of the city (Kartal, 1977). Since the conversion of rural land to urban land cannot meet the speed of increase in needs and demands of urban life, it causes an extreme increase in the value of existing urban lands 
(Keleş et al., 1999; Müderrisoğlu, 2006). Each urban function requires certain amount of urban land according to the growth direction and extent of its development perspective (Harvey, 1996). The demand from both the public and private sectors for the establishment of the required urban buildings increase the value of the land in a continuous manner. In real, the production is not land but value added. The conversion of the land from rural to urban land (agricultural land to urban land parcel), consequently being subject to the infrastructure investments and building of the urban facilities for the public usage such as roads, parking areas, green areas and etc. increases the value of the land in a circular phase (Keleş, 2004). Furthermore, factors such as the chances in economic and social conditions and illegal construction actions accelerate the profiteering activities and enhance their scope compared to the value increases in normal conditions (Keleş et al., 1999).

\section{URBAN LAND AND ITS PROPERTIES}

In order to a land to earn the urban land qualification, it should have infrastructure, urban development rights and superstructure completely. The owners of these lands can possess various rents such as accessibility, social statue, wealth accumulation and income transfer in line with the urban activities (Ertürk, 1995, pp. 161-162). Urban land provides areas for various functions and the owner of the land can handle to gain rent by carrying out these activities by himself or can give the usage rights to others (Tekeli, 2009). Urban land provides rent to the land owner primarily by being within the city and its position. The rent ratio accelerates while urban services and activities is upgraded. The location preferences within the city generally are closely related with social statue and income distribution. The owners of urban land can create social layers by creating a settlement area through their preferences and this situation can provide social statue for the land owner. Growth of cities leads the urban land structure to change comparatively and increase the value of the land on the developing region. In this case, the urban land maintain the accumulation of the land owner to resist against inflation. By this way, urban land allows accumulation of wealth without even under inflationary conditions (Ertürk, 1995). The value of urban lands which are placed on the route of urban development increase rapidly as they become central and their functions change. This situation leads the land owner to receive this value added created without expending any effort. The receipt of the socially created value added by the land owner without any effort is such a function of income transfer (Ertürk, 1995).

In general urban land owns five main characteristics. These are; 1) continuous change in its value, 2) continuous change of its comparative location within the city, 3) its openness to the external factors' uncontrolled by the land owner, 4) possessing multi functions and 5) continuous change of its characteristics in time (Kartal, 1977). We can define the characteristics of urban land by taking these five main characteristics: a) In order that the lands of the urban areas to be qualified as urban lands, infrastructure should be maintained, the development rights should be determined by zoning plan, urban parcels should be defined and superstructure should be determined on the basis of infrastructure and zoning plans, b) the values of urban land are determined by the integrity of infrastructure, development rights and superstructure. These three factors qualify the land to be available for production. Settlement and other urban services increases in line with the increasing demand following the natural expansion of population and migration. In this case, if the demand for transformation from rural lands to urban land parcels cannot be met with the same ratio, the value of the existing urban land increases without any effort, c) rural lands also earn the qualification of urban land with infrastructure, zoning rights and superstructure decisions. However, the potential of the new urban lands annexed to the city in line with the need and decisions to create scarcity and absolute rent is related with their location within the city, d) the decisions on the production 
and transformation of the components of urban land have different characteristics. Infrastructure and superstructure decisions require highly important investment perspectives and are long term economic based decisions. On the other hand zoning decisions are administrative decisions and generally made under political pressures and amended frequently, e) infrastructure decisions should be taken into account when the development rights are decided in line with the urban planning rules. However it is a frequently experienced fact that development rights are made under political pressures and administratively without taking the prospective infrastructure insufficiencies into account, f) urban functions according to their prospective development route and extent of the city require a certain urban land and in time the land circling the city may become comparatively central as the city expands. By this way, even if the infrastructure and development rights factors do not amend the value of these lands increase. Consequently, the value of the land increases with the changing comparative position within the city and this is a general shift, g) as a result of various changes in the society (urban transformation, applications related with the disaster regions or the emergence of new secondary centers etc.) a new added value can be created for the land owner without any labor or capital investment, h) in time the change of the value of the land within the city depends on the factors out of the control of the land owner such as its distance from administrative, leisure or trade centers. The land owner has to accept these changes which are occurring out of his/her control, i) in accordance with the public interest, the value of a land may increase with the arrangements for urban services and this increase is unavoidable but a land with limited zoning can lead the a very high increase. Following the zoning decision the value of a land may highly accelerate. If a special zoning decision is made, the urban land will be subject to a favored increase of value by taking a political decision promoting the pressure and interest groups mentioned in the fourth item above, $\mathrm{j}$ ) trade and service areas are the main guidance of urbanization process and creating higher rent in settlement zones by enhancing economic activities within the city. These activities and services create value increases on settlement areas. On a settlement region, the highest value of land occurs on these functional areas. By the way, the selection of trade and service locations is highly important. On the other hand, trade areas also have differentiated valuation in each (parking opportunities, transportation facilities, construction rights and location etc.), k) urban land is used for multi purposes (functions). Generally, the urban land can be expanded within the city scope but the urban land cannot be expanded for specific functions. Consequently, urban land for these special functions owns the characteristic of monopoly. This monopolistic character provides the land owner of the relevant land an abnormal earning at the expense of the public interest (Keleş, 2004, pp. 599-603; Ertürk, 1995; Kartal, 1977).

\section{LAND SPECULATION IN TURKEY}

"Profiteering on the urban land is seen as a natural result of the high levels of urban land rents" (Keleş et al., 1999, p. 44). Land speculation is the name of land owners' attitude to keep their land vacant, overestimate its value to utilize any future opportunity of value increases -with the expectation of a scarcity or monopoly rent- or purchasing land with the same aim. This situation avoids a planned development of the cities consequently effects the urban planning process negatively which is the main instrument of regular urbanization. The unfunctioning of the planning process leads unhealthy and irregular development of the cities. One of the main reasons for unplanned urbanization is land speculation in Turkey. Land speculation avoids the development of the urbanization according to the planned development axes, settlement densities and transportation hierarchy by effecting urbanization decisions (K1lınçaslan, 2010). Keeping the urban land vacant for increasing the land scope hinders the effective usage of urban services and the process of defining the location of services become 
more difficult (Kılınçaslan, 2010). On the other hand, there emerge extensive new settlements on the cheaper lands surrounding the city. Because the urban services cannot find proper places due to land profiteering leads the cities to grow in a discrete pattern. With this way, land speculation causes unnecessarily spatial expansion of the cities. Keeping the lands vacant in the cities vacant and their high values causes the emergence of new settlement areas on the extensive area around the city. This situation leads increasing costs of urban services. Furthermore, speculation is not only on the unbuilt lands. Permissions on increasing the densities on the settled lands either because of the increasing population or political pressures causes demolishing of the buildings before the end of their utilization period. On the existing settlement areas, speculative profits can be earned by creating value increases on the basis of transformation to new urban functions or increasing the construction rights (Keleş, 2004; Ertürk, 1995). This density expansion before the provision of requirements of urban and social life within the standards leads the experience of lower living standards in these settlement areas (Tekeli, 2009).

There exist interest groups which carry out the land speculation regularly as their profession and these people are known as land richmen who make speculation as a profession in Turkey (Keleş, 2014, p. 147). These people purchase lands within the urban development axes and keep these lands vacant and enforce the redundant expansion of the cities. This type of speculations are called active speculation (Keleş, 2014). On the other hand, there are people who invest their accumulation in landed property with investment targets to receive profit. These people are comparatively passive people and do not carry out land purchasing activities with the strong motivation like the speculators. These people are called passive (inactive) speculators. Related with the results caused by these two types of speculations and their effect on the public interest, there is a degree difference rather than a context difference (Keleş and Mengi, 2017). Within the systems with private ownership, it is clear that land ownership leads undeserved earnings on the urban areas. It is hard to make a clear definition of ownership which will be eligible for all legal systems. Ownership refers to the possession of goods according to both traditional and legal structure such as cultural processes, economic and social structure, legal order and social statue (AnaBritanica, 16). Property rights provide individuals the rights to dispose, use and utilize the land. Right of disposing is the right that the owner can sell, grant and even destroy the object of the right. Using right gives the owner the right to use the object of the right anytime and for any duration. Utilization right gives the owner the right to utilize the object of the right either by using himself or renting it (Genel Ekonomi Ansiklopedi, 1998; Kılınçaslan, 2010). There are four main components of property rights system. These are possessing the property, transferring the property, right of using the property and responsibilities and limitations against abusing the property rights (Keleş et al., 1999).

Property right has been defined by the Constitution Article 35 as "Everyone has the right of property and inheritance. These rights can only be limited by laws and for the interest of the public. The usage of the property rights cannot be against the public interest." and determines that individuals do not hold an absolute property right on the land and endows the state with the authority to avoid any misuse of the property right and limit the usage of the right. This article is a legal reference for avoiding land speculations and limiting the private property rights used by individuals (Keleş and Mengi, 2014, p. 36). Zoning plan decisions should be developed by consideration of public interest. Decisions taken within the zone planning process can amend the macroform of the city and can provide new opportunities for the speculators to get richer. Consequently, preserving the zone planning processes from the active speculators who are generally wealthy people and try to interfere to the processes and provision of public interest efficiently depends on the administrative procedures. Zoning 
concept refers to betterment, healing, developing and provision of services. According to the $35^{\text {th }}$ article of the Constitution mentioned above, the zoning decisions should provide equitable and fair urban, environmental and social places for each individual living in the cities. However, active or passive speculation of land and rent as a reason and result of land speculation is an unavoidable result of systems with private ownership. This situation leads the creation of absolute rent even in the most rational and ethic decision taking processes and provides undeserved incomes for the speculators (Campbell and Marsall, 2000).

\section{CONCLUSION AND ASSESSMENTS}

Private ownership is related with absolute rent and absolute rent is related with land speculation. Because of the land speculation, lands are kept vacant in the cities or no purchaser can not be found because of high prices. Interest groups receive undeserved earnings with land speculation and this situation leads inequality in income distribution (Keleş, 2004; Kartal, 1977). The existence of private ownership in urban land causes parceling the land. As the areas between buildings cannot be unified or optimized, the common usage areas cannot be developed and there emerges small places which are useless. Parceling because of private ownership and land speculation cause individual construction rights, and this situation abandons an integral planning of the city (Tekeli, 2009). Land speculation arises from the fact that land is an immovable resource and the expectation and information on the upcoming investments around it automatically increase the value (Kilınçaslan, 2010). This process is used to get undeserved earnings. Nowadays, rent and land speculation are used interchangeably and defined as an undeserved income without any attempt (Yurtsever, 2010). On the urban land subject to the ownership, zoning plans limit the using right of the land owner in various ways. Zone planning can be used to avoid rents on urban lands or minimize and stream the rent to public benefit (Keleş et al., 1999). In the systems with private property rights, creation of rents which arise from scarce nature of the lands is unavoidable. The development routes of the cities and property structures should be carefully taken into account within the planning process. Otherwise frequently amended zoning plans will promote speculative activities and by providing available conditions for land speculations come out as an instrument (Keleş et al., 1999).

The creation of the urban land is a result of intervention in the planning process. The intervention, pressure and enforcements of the central and local administration, land owner, political figures, constructers, and interest groups effect the planning process and lead the urban development through the lands subject to the speculation rather than the requirements of the planning. The urban rents arising from the increasing value of urban lands is controlled by the planning decisions, the actions and investments of public sector, pressure and interest groups, speculators, land owners and political figures. Even it is difficult to avoid scarcity and monopoly rents arising from the spatial characteristics of the land, it is possible and necessary to avoid absolute rent (Keleş et al., 1999). Avoiding absolute rent which is caused by the misuse of property rights will support the avoidance of scarcity and monopoly rents' potential to threat the public interest and also all other urban and social problems caused by undeserved earnings. Urban vital requirements need land within the existing urban lands or on the city's extension. The land owners' attitude to keep the land vacant or keep the price high in order to receive more income causes the scarce lands to be wasted and cities to grow in an extensive and discrete way. Lower income groups are pushed to create their own living spaces because of these speculative activities. Especially the emergence of slums around the cities or on the industrial locations due to the migration from rural to urban within the industrialization process is assessed as a result of land speculation. Residence which is the main instrument of settlement and sheltering is an indicator of life style. Slum concept on the other hand is a 
result of insolubility or dissolution and caused by a list of administrative, social and economic factors to solve the problems of land speculation and legal regulations. There is a mutual relation between urban, land and rent but this relation contradicts property rights and development rights. The transition of rural land to urban land with market movements and zoning increases the value of the land. On the other hand existing or created scarcity (scarcity can be created due to the functionality of the land on the view of the land owner, by keeping the vacant, trade of the land with speculative activities, high valuation of the land compared to the real value, keeping the public land out of utilization, scant zoning plans, limitations of land supply or general characteristics of land) of the rural land leads rural lands' values to shrink. The extension of cities though the margins due to the increasing population and demands causes the pressures and developments for the production of new lands at the margins. Because of the extension of the cities through the margins the transportation, production and market relations change and land prices increase through center with the effect of rent. Depending on the scarcity rent, the revalued parcels through the city center become subject to pressures for amendment of utilization and construction conditions. The adverse relation between revalued land created within the rent and land relation and previous buildings which have finished their utilization lives pave the way for emergence of ideal conditions for transformation and realization of the accumulation of rent (Keleş and Mengi, 2017; Meydan, 2011).

Transformation processes fed by the rent also promotes the value increase of the land in turn. Following the urban transformation the scarcity of the urban land and increasing value of the central lands with the developing urban conditions can cause alternative channels of land production become functional. Pressures for the public parcels to be valued on the land values or pressures on the public parcels to be sold to the private sector are among these channels. These processes generally work with planning processes and are experienced as purchasing of the public parcels especially allocated for outfitting areas, undervalued by the private sector. After the purchase and change of ownership, due to the changing utilization, development rights are reregulated for the revalued parcels; the earned rights stemming from rent effect but not any work are updated and further increased. All these processes under the headings of physical transformation change and development can be viewed as expropriation on the accumulated rent. In order to maximize rent effect, development rights are increased and land costs are reduced in transformation parcels, re-utilization funding requirements are maximized by re-motioning the user groups and integral planning decisions are destabilized by plan amendments which are not consistent with planning decisions. Land rent has become an investment tool which gives direction to urban development and expansion decisions. Consequently this mutual relation between urban and rent affects environment and protection policies as well. It is necessary to abolish absolute rent, expropriation of land in the primary protection areas, exact prediction of the growth routes of the cities in planning process, take care of ownership structure, and maintain an equal distribution of the rent on spatial basis end most important to avoid zoning activities from interventions and frequent amendments (Meydan and Emür, 2013). Urban land is an aggregate of infrastructure, development rights and superstructure. Minimizing frequent amendments on zoning plans, the intervention from political actors, pressure and interest groups on investment decisions will maintain the utilization of local dynamics for public interest and will abolish income differences. 


\section{REFERENCES}

Akın, E. (2008). Rant ve planlamada uzlaşma: yerel yönetimler, yerel yönetimlerde katılım, Mimarlık Dosya Dergisi, 64: 50-53.

Aktan, Coşkun C., (1993). Politikada rant kollama, Amme İdaresi Dergisi, (December), 26(4), 119-136.

Alkan, A. (1991). City, Urbanization and Family, Türk Aile Ansiklopedisi, Ankara: Türkiye Yazarlar Birliği Vakfı, Birim Basın-Yayın Organizasyon, 3: 960-967.

AnaBritannica Genel Kültür Ansiklopedisi, Volume: 16.

AnaBritannica Genel Kültür Ansiklopedisi, Volume: 26.

Bahçeci, H. I. (2016). Capital accumulation as a tool for urban rent in Turkey, Journal of USChina Public Administration, 13(2), 122-135.

Campbell, H. ve Marsall, R. (2000). Moral obligations, planning and the public interest: a commentary on current British practice, Environment And Planning, 27: 297-312.

Dinler, Z. (2008). İktisada giriş, 14. Bask1, Bursa: Ekin Kitabevi.

Eceral, T., Varol, Ç., Alkan, L. (2010). Urban land valuation process: the case of Ankara, Mustafa Kemal Mahallesi, Toprak Mülkiyeti Sempozyum Bildirileri içinde (pp. 307-325), Ankara: Memleket Yayınları.

Ertürk, H. (1995). Kent ekonomisi, 1. Bask1, Bursa: Ekin Kitabevi.

Genel Ekonomi Ansiklopedisi (1998). Milliyet Yayınları, 2: 950.

Harvey, D. (1996). Social justice and the city, (Translated: M. Moral1), İstanbul: Metis Yayınları.

Kartal, S. K. (1977). Problems of arising from the urban land of private property rights, Amme İdaresi Dergisi, 10(2), 17-48.

Keleş, R. (2014). 100 soruda Türkiye'de kentleşme, konut ve gecekondu, 1. Basım, İstanbul: Cem Yayınları.

Keleş, R. (2004). Kentleşme politikası, Ankara: İmge Kitabevi.

Keleş, R. ve Mengi, A. (2017). Kent hukuku, Ankara: İmge Kitabevi.

Keleş, R. ve Mengi, A. (2014). İmar hukukuna giriş, Ankara: İmge Kitabevi.

Keleş, R., Geray, C., Emre, C. ve Mengi, A. (1999). Toprak rantının kamuya kazandırılması, Ankara: Öteki Yayınları.

Kılınçaslan, İ. (2010). Urban economics, sectoral development, economic geography, applied economics, structural analysis, İstanbul: Ninova Yayınları.

Marx, K. (1978). Capital, (Translated: A. Bilgi), Ankara: Sol Yayınları.

Meydan Larousse Büyük Lugat ve Ansiklopedi, 1(16), 487-492.

Meydan, S. G., (2011). Kentsel toprakta değer artış süreci kentleşme ve kentsel rant ilişkisi: Kayseri örneği, Yayınlanmamış yüksek lisans tezi, Erciyes Üniversitesi, Kayseri.

Meydan, S. G. ve Emür, S. H. (2013). Kentleşme ve kentsel rant ilişkisi: Kayseri örneği, Çăgdaş Yerel Yönetimler Dergisi, 22(4), 51-73.

Müderrisoğlu, B. (2006). Kentsel rantın dönüşümü ve yerel yönetimler, Yayınlanmamış yüksek lisans tezi, Marmara Üniversitesi, İstanbul. 
Tekeli, İ. (2009). Kentsel arsa, altyapr ve kentsel hizmetler, İstanbul: Türk Tarih Vakfı Yurt Yayınları.

Turan, M. (2009). Türkiye'de kentsel rant: devlet mülkiyetinden özel mülkiyete, Ankara: Tan Yayınları.

Yurtsever, H. (2010). Rantın vergilendirilmesi, Toprak Mülkiyeti Sempozyum Bildirileri içinde (pp. 385-399), Ankara: Memleket Yayınları. 